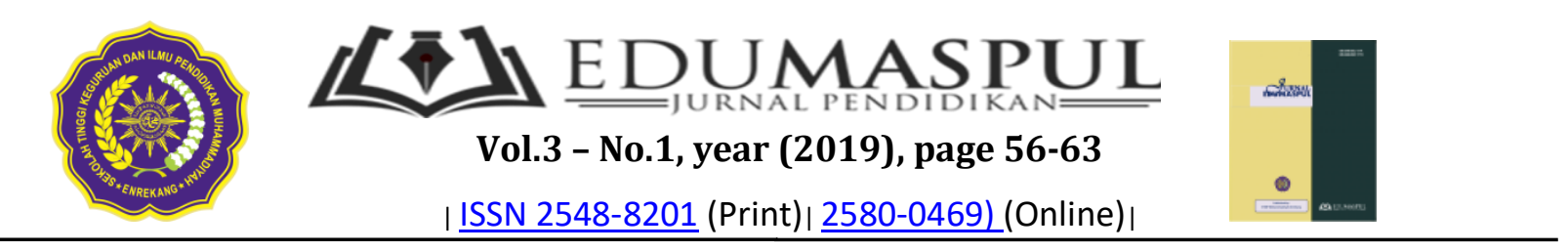

\title{
Applying ELSA Speak Software in the Pronunciation Class: Students' Perception
}

\author{
Ita Sarmita Samad; Aminullah Aminullah \\ STKIP Muhammadiyah Enrekang, Indonesia \\ * Corresponding Author. E-mail: itaneverendita@gmail.com aminullahbiologi@gmail.com
}

Receive: $12 / 01 / 2019$

Accepted: 22/03/2019

Published: 02/04/2019

\begin{abstract}
This study aims at finding out the students' perception towards the application of ELSA Speak software in their pronunciation class. A total number of 12 students are involved in this present study. Descriptive quantitative research design is applied in this study. It utilizes questionnaire to collect data and Likert-Scale to analyze the data. The result shows that students consider that the software is very good to be applied in learning pronunciation.
\end{abstract}

Keywords: ELSA Speak Software, Perception, Pronunciation

\section{INTRODUCTION}

Pronunciation is one of the crucial parts of learning to speak a foreign language. It is because pronouncing words improperly can lead to negative impression, misunderstanding and ineffective communication (Englishcentral, 2015). In terms of speaking especially in daily conversation, the limited vocabulary is not a big matter as the complicated words can be expressed in other simple words that have been known. On the contrary, the pronunciation is the first thing that the native speaker will be aware of along the conversation. Thus, they can perceive that a man is bad in English simply because he/she has poor pronunciation. Besides, misunderstanding can occur because of this bad pronunciation. A seller as native speaker can give wrong item when a foreign buyer says the item incorrectly. Even worse, it can be presumed that a man is rude although she/he does not mean it to be. Additionally, mispronunciation can lead to an ineffective communication. It will bother the native speakers to ask the foreigner to keep repeating their utterance as an effort to understand what they are actually trying to say.

One of the issues faced by the EFL students in pronunciation is the influence of their mother tongue. Sholeh and Muhaji (2015) claimed that most of the students' pronunciation in Indonesia is still affected by their native language. Accordingly, the students are difficult to speak English naturally. Their utterances are sounded 
like English with Indonesian character. Moreover, Indonesian is varied in terms of their dialect or accent. Then, most of the students will be influenced by their own dialect or accent following their region.

In fact, the students of STKIP Muhammadiyah Enrekang in English Education Program face the problem above as well. The students are mostly from Enrekang regency but they also have various dialects. Therefore, their English speaking is characterized by their own dialect. Yet, it cannot be ignored that there is a few of them that have been good enough in pronouncing the English words. They can deal with this problem.

Besides, it is found that the quantity of time that the students have to listening to the English native speakers also affects their pronunciation. The preinterview that the researcher has done to the study's subject shows that most of the students listen to the English rarely. Consequently, they are not accustomed with the way the English native speakers saying the words.

Using appropriate teaching media can help students to be capable in pronouncing the words properly. Moreover, the use of technology as one of the forms of media is recommended nowadays. Some studies support this notion. Sasmita (2012), Amri and Gusmina (2013), Erniwati, Syafar, and Marnalita (2013) are some researchers who had found that it is effective to use the kinds of technology in helping students to have a good pronunciation.

There are so many technologies can be downloaded from the internet. In terms of pronunciation practice, there is software namely "ELSA Speak: English Accent Coach" which is can be downloaded through play/app store on smart phone. It is designed to help learners to speak English clearly, fluently, and confidently ("7 Best English pronunciation
Apps," 2019). The features provided in this app are designed to exercise the learners to say the words correctly such as vowel, consonant, word stress.

Nowadays, almost all of the university students have the internet on their hands and so do the third semester students of English education program of STKIP Muhammadiyah Enrekang. All of them have a smart phone that they can utilize to access the internet. Thus, they should exploit the internet for the positive purpose. The lecturers can give their contribution to lead their students to the productive use of internet as well. One of the ways is by introducing them to the sources of app that they can use as a media in learning English.

It is seen that the students were enthusiastic when the researcher as their lecturer asked them to practice their English pronunciation through this app. Yet, there is no scientific data that shows the students' opinion towards the ELSA Speak app. Therefore, this research is designed to investigate their perception. This is important to do considering that the result would influence the teaching and learning of the pronunciation practice.

\section{METHODOLOGY}

\section{Research Design}

A descriptive quantitative research design is applied in this research. It is designed to explore the students' perception towards the use of ELSA Speak app in learning pronunciation. Questionnaire was used to collect the data.

\section{Population}

The population of this research is the English education program of STKIP Muhammadiyah Enrekang in academic program of 2018/2019. Meanwhile, the sample is the third semester students of the program with total 12 students. It is settled 
on through purposive sampling. The consideration is that the students were programming the pronunciation subject at that time.

\section{Research Instrument}

This research used questionnaire to collect the data. The questionnaire was based on the EFL/ESL pronunciation teaching software evaluation instrument which is designed by Martins, Levis and Borges (2016). The number of the questionnaire is 72 items. It is designed to view on at least 5 main points: the content, pedagogical, assessment/ flexibility, multimedia, and automatic speech recognition design.

The data collected based on the questionnaire was analyzed using likertscale (Jainuri, 2014). The steps are explained as follows:

a. The researcher determined the total of maximal score (Max). That is the maximal score $(\max )$ of each respondent times the total respondent $(\mathrm{N})$.

$$
\operatorname{Max}=\max * \mathrm{~N}
$$

b. The researcher determined the total of minimal score (Min). That is the minimal score (min) of each respondent times the total respondent (N).

Min $=\min * \mathrm{~N}$

c. The researcher determined the median score $(\mathrm{Me})$. That is the total of maximal score (Max) plus the total of minimal score (Min). Then, the result is divided by two.

$\mathrm{Me}=\frac{(\text { Max }+ \text { Min })}{2}$

d. The researcher determined the quarter 1 score (Q1). That is the total of minimal score (Min) plus median. Then, the result is divided by two.

$\mathrm{Q} 1=\frac{(M i n+M e)}{2}$

e. The researcher determined the quarter 3 score (Q3). That is the total of minimal score (Max) plus median. Then, the result is divided by two.

$$
\mathrm{Q} 3=\frac{(M a x+M e)}{2}
$$

f. The researcher made a scale describing the total of minimal score, quartil 1, median, quartil 3 , and the total of maximal score.

Figure 1. The Scale of Score Category

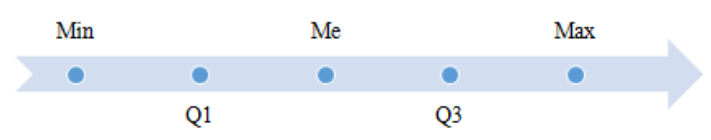

g. The researcher made score limitations for each attitude category.

Table 1. The interval score

Attitude Interval Interval

Score

\begin{tabular}{cc}
\hline $\begin{array}{c}\text { Strongly } \\
\text { Agree } \\
\text { Agree }\end{array}$ & $\mathrm{Q} 3 \leq \mathrm{x} \leq \mathrm{Max}$ \\
Disagree & $\mathrm{Q} 1 \leq \mathrm{x}<\mathrm{Q} 3$ \\
& $\mathrm{Me}$ \\
Strongly & $\mathrm{Min} \leq \mathrm{x}<\mathrm{Q}$ \\
Disagree & \\
\hline
\end{tabular}

h. The researcher determined the total score of the whole respondents (x). That is the sum of the total scores obtained by each respondent.

\section{THE RESULTS}

\section{a. The students' perception regarding on the ELSA Speak's content design}

There are 13 items of the questionnaire that concerning on the content design of the ELSA Speak software. The total score of the students' answer is 526. The maximal (Max), minimal (Min), median (Me), quadrant 1 (Q1), and quadrant 3 (Q3) of the students' score regarding the content design can be seen in the scale 2 below. 
Figure.2 The Scale of the Content Design

$\begin{array}{ccccc}\operatorname{Min}(0) & & \mathrm{Me} & & \mathrm{Max} \\ & & (312) & & (624) \\ & \bullet & \bullet & \bullet & \bullet \\ & \mathrm{Q} 1 & & \mathrm{Q} 3 & \\ & (156) & & (468) & \end{array}$

The data can be categorized from strongly agree to strongly disagree as the following table.

Table.2 The Interval Score of the Content Design

\begin{tabular}{ccc}
\hline Attitude & Interval & Interval \\
& & Score \\
\hline $\begin{array}{c}\text { Strongly } \\
\text { Agree } \\
\text { Agree }\end{array}$ & $\mathrm{Q} 3 \leq \mathrm{x} \leq \mathrm{Max}$ & $468 \leq \mathrm{x} \leq 624$ \\
Disagree & $\mathrm{Q} 1 \leq \mathrm{x}<\mathrm{Q} 3$ & $312 \leq \mathrm{Me} \leq 468$ \\
& $156 \leq \mathrm{x} \leq 312$ \\
$\begin{array}{c}\text { Strongly } \\
\text { Disagree }\end{array}$ & $\mathrm{Min} \leq \mathrm{x}<\mathrm{Q} 1$ & $0 \leq \mathrm{x} \leq 156$ \\
\hline
\end{tabular}

b. The students' perception regarding on the ELSA Speak's pedagogical design

The second category that is analyzed in this research is about the pedagogical design of the ELSA Speak application. There are 24 items of the questionnaire regarding on this category. The total score of the students' answer is 845. The Figure 3 shows the maximal, minimum, median, quadrant 1 , and quadrant 3 score of this category. Meanwhile the table 3 shows the interval score of the pedagogical design.

Figure.3 The Scale of the Pedagogical Design

$\begin{array}{ccccc}\text { MIn (0) } & & \text { Max } & \text { Me (576) } & \\ (1152)\end{array}$

Table.3 The Interval Score of the Pedagogical Design

\begin{tabular}{ccc}
\hline Attitude & Interval & Interval \\
& & Score \\
\hline $\begin{array}{c}\text { Strongly } \\
\text { Agree }\end{array}$ & $\mathrm{Q} 3 \leq \mathrm{x} \leq \mathrm{Max}$ & $864 \leq \mathrm{x} \leq$ \\
Agree & $\mathrm{Me} \leq \mathrm{x}<\mathrm{Q} 3$ & $576 \leq \mathrm{x} \leq 864$ \\
Disagree & $\mathrm{Q} 1 \leq \mathrm{x}<\mathrm{Me}$ & $288 \leq \mathrm{x} \leq 576$ \\
$\begin{array}{c}\text { Strongly } \\
\text { Disagree }\end{array}$ & $\mathrm{Min} \leq \mathrm{x}<\mathrm{Q} 1$ & $0 \leq \mathrm{x} \leq 288$ \\
\hline
\end{tabular}

c. The students' perception regarding on the ELSA Speak's assessment/ flexibility design

There are 10 items in the questionnaire that containing question concerning on the applications' assessment/ flexibility design. The total score of the students' answer is 361 . Summing it up, the figure 4 shows the scale of the score from the minimum to the maximum. Then, table 4 shows the interval score for each category: strongly agree, agree, disagree, and strongly disagree.

Figure.4 The Scale of the Assessment/ Flexibility Design

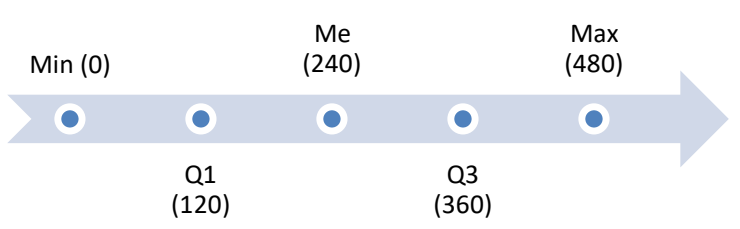

Table.4 The Interval Score of the Assessment/ Flexibility Design 


\begin{tabular}{ccc}
\hline Attitude & Interval & Interval \\
& & Score \\
\hline $\begin{array}{c}\text { Strongly } \\
\text { Agree } \\
\text { Agree }\end{array}$ & $\mathrm{Q} 3 \leq \mathrm{x} \leq \mathrm{Max}$ & $360 \leq \mathrm{x} \leq 480$ \\
Disagree & $\mathrm{Q} 1 \leq \mathrm{x}<\mathrm{Q} 3$ & $240 \leq \mathrm{Me} \leq 360$ \\
& $120 \leq \mathrm{x} \leq 240$ \\
$\begin{array}{c}\text { Strongly } \\
\text { Disagree }\end{array}$ & $\mathrm{Min} \leq \mathrm{x}<\mathrm{Q} 1$ & $0 \leq \mathrm{x} \leq 120$ \\
\hline
\end{tabular}

d. The students' perception regarding on the ELSA Speak's multimedia design

There are 19 items in the questionnaire that containing question concerning on the applications' multimedia design. The total score of the students' answer is 687 . Summing it up, the figure 5 shows the scale of the score from the minimum to the maximum. Then, table 5 shows the interval score for each category: strongly agree, agree, disagree, and strongly disagree.

Figure.5 The Scale of the Multimedia Design

$\begin{array}{ccccc}\begin{array}{ccc}\text { Min } \\ (0)\end{array} & & \begin{array}{c}\text { Me } \\ (456)\end{array} & & \begin{array}{c}\text { Max } \\ (912)\end{array} \\ 0 & 0 & 0 & 0 & 0 \\ & \text { Q1 } & & \text { Q3 } & \\ & (228) & & (684) & \end{array}$

Table.5 The Interval Score of the Multimedia Design

\begin{tabular}{ccc}
\hline Attitude & Interval & Interval \\
& & Score \\
\hline $\begin{array}{c}\text { Strongly } \\
\text { Agree } \\
\text { Agree }\end{array}$ & $\mathrm{Q} 3 \leq \mathrm{x} \leq \mathrm{Max}$ & $684 \leq \mathrm{x} \leq 912$ \\
Disagree & $\mathrm{Q} 1 \leq \mathrm{x}<\mathrm{Me}$ & $456 \leq \mathrm{x} \leq 684$ \\
& & $228 \leq \mathrm{x} \leq 456$
\end{tabular}

\begin{tabular}{lll}
\hline $\begin{array}{l}\text { Strongly } \\
\text { Disagree }\end{array}$ & Min $\leq \mathrm{x}<\mathrm{Q} 1$ & $0 \leq \mathrm{x} \leq 228$ \\
\hline
\end{tabular}

e. The students' perception regarding on the ELSA Speak's automatic speech recognition design

There are 6 items in the questionnaire that containing question concerning on the applications' automatic speech recognition design. The total score of the students' answer is 178. Summing it up, the figure 6 shows the scale of the score from the minimum to the maximum. Then, table 6 shows the interval score for each category: strongly agree, agree, disagree, and strongly disagree.

Figure.6 The Scale of the Automatic Speech Recognition Design

\begin{tabular}{|c|c|c|c|c|}
\hline $\operatorname{Min}(0)$ & & $\begin{array}{c}\mathrm{Me} \\
(144)\end{array}$ & & $\begin{array}{c}\text { Max } \\
(288)\end{array}$ \\
\hline - & - & $\bullet$ & - & - \\
\hline & Q1 (72) & & $\begin{array}{l}\text { Q3 } \\
(216)\end{array}$ & \\
\hline
\end{tabular}

Table.6 The Interval Score of the Automatic Speech Recognition Design

\begin{tabular}{ccc}
\hline Attitude & Interval & Interval \\
& & Score \\
\hline $\begin{array}{c}\text { Strongly } \\
\text { Agree } \\
\text { Agree }\end{array}$ & $\mathrm{Q} 3 \leq \mathrm{x} \leq \mathrm{Max}$ & $216 \leq \mathrm{x} \leq 288$ \\
Disagree & $\mathrm{Q} 1 \leq \mathrm{x}<\mathrm{Me}$ & $144 \leq \mathrm{x} \leq 216$ \\
$\begin{array}{c}\text { Strongly } \\
\text { Disagree }\end{array}$ & $\mathrm{Min} \leq \mathrm{x}<\mathrm{Q} 1$ & $0 \leq \mathrm{x} \leq 72$ \\
\hline
\end{tabular}

\section{f. The calculated data of all of the questionnaire items}

The total number of the questions in the questionnaire is 72 items. The total score of the students' answer is 2597. Summing 
it up, the figure 6 shows the scale of the score from the minimum to the maximum. Then, table 6 shows the interval score for each category: strongly agree, agree, disagree, and strongly disagree.

Figure.7 The Scale of the Students' Perception on the entire categories

$\begin{array}{ccccc}\operatorname{Min}(0) & & \begin{array}{c}\text { Me } \\ (1728)\end{array} & & \begin{array}{c}\text { Max } \\ (3456)\end{array} \\ \bullet & \bullet & \bullet & \bullet & \bullet \\ & \text { Q1 } & & \text { Q3 } & \\ & (864) & & (2592) & \end{array}$

Table.7 The Interval Score of the Students' Perception on the entire categories

\begin{tabular}{|c|c|c|}
\hline Attitude & Interval & $\begin{array}{l}\text { Interval } \\
\text { Score }\end{array}$ \\
\hline $\begin{array}{c}\text { Strongly } \\
\text { Agree }\end{array}$ & $\mathrm{Q} 3 \leq \mathrm{x} \leq \mathrm{Max}$ & $\begin{array}{c}2592 \leq x \leq \\
3456\end{array}$ \\
\hline Agree & $\mathrm{Me} \leq \mathrm{x}<\mathrm{Q} 3$ & $\begin{array}{c}1728 \leq x \leq \\
2592\end{array}$ \\
\hline Disagree & $\mathrm{Q} 1 \leq \mathrm{x}<\mathrm{Me}$ & $\begin{array}{c}864 \leq x \leq \\
1728\end{array}$ \\
\hline $\begin{array}{l}\text { Strongly } \\
\text { Disagree }\end{array}$ & $\operatorname{Min} \leq \mathrm{x}<\mathrm{Q} 1$ & $0 \leq x \leq 864$ \\
\hline
\end{tabular}

\section{DISCUSSIONS}

\section{a. The students' perception regarding} on the ELSA Speak's content design

The result of the questionnaire regarding the students' perception towards the content design of the ELSA Speak software shows the total score of the students' answer is 526. It exists in the interval score of Q3 and maximum score. Thus, it means that it is included in the strongly agree category.
Based on the data, it can be stated that the students consider that the content design of the ELSA Speak software is very good. Accordingly, it can be interpreted that the program highly addresses the content according to the proposed objective and proficiency level. In addition, the program also addresses the vowel sounds, the diphthongs, the consonant sounds, syllabic constituent, word/ sentence stress, prominence, connected speech phenomena, and intonation in a good way.

\section{b. The students' perception regarding on the ELSA Speak's pedagogical design}

The result of the questionnaire regarding the students' perception towards the pedagogical design of the ELSA Speak software shows the total score of the students' answer is 845. It exists in the interval score of Median and Quadrant 3 score. Thus, it means that it is included in the agree category.

Based on the data, it can be stated that the students consider that the content design of the ELSA Speak software is good. Hence, it can be assumed that the program contrasts different vowel sounds and different consonant sounds as well. Besides, it also presents and distinguishes grammatical and semantic intonation patterns as well. The program uses phonetic symbols and transcriptions. It also presents the contents organized sequentially. Regarding the activities, it works on clearly production of sounds and instructions.

\section{c. The students' perception regarding on the ELSA Speak's assessment/ flexibility design}

The result of the questionnaire regarding the students' perception towards the assessment/ flexibility design of the ELSA Speak software shows the total score of the students' answer is 361. It exists in the interval score of Quadrant 3 and Maximal 
score. Thus, it means that it is included in the strongly agree category.

Based on the data, it can be stated that the students consider that the assessment/ flexibility design of the ELSA Speak software is very good. The students strongly agree that regarding the feedback of the activities, it gives good explanation. In addition, regarding the activities, the students can choose their difficulty level and know the result as well.

\section{d. The students' perception regarding on the ELSA Speak's multimedia design}

The result of the questionnaire regarding the students' perception towards the multimedia design of the ELSA Speak software shows the total score of the students' answer is 687. It exists in the interval score of Quadrant 3 and Maximal score. Thus, it means that it is included in the strongly agree category.

Based on the data, it can be stated that the students consider that the multimedia design of the ELSA Speak software is very good. It can be interpreted that the students consider that the multimedia such as the installation, the animation, the images, the sounds are designed in a very good way.

\section{e. The students' perception regarding on the ELSA Speak's automatic speech recognition design}

The result of the questionnaire regarding the students' perception towards the automatic speech recognition design of the ELSA Speak software shows the total score of the students' answer is 178. It exists in the interval score of Median and Quadrant 3 score. Thus, it means that it is included in the agree category.

Based on the data, it can be stated that the students consider that the automatic speech recognition design of the ELSA Speak software is very good. It can be assumed that the students agree that the program uses automatic speech recognition to provide immediate feedback on the user's pronunciation and allows the user to calibrate the automatic speech recognition.

\section{f. The students' perception regarding on the ELSA Speak Software}

The result of the whole items of the questionnaire regarding the students' perception towards the ELSA Speak software shows the total score of the students' answer is 2597. It exists in the interval score of Quadrant 3 and Maximal score. Thus, it means that it is included in the strongly agree category.

Based on the data, it can be assumed that the students think that the ELSA speak is very good to be used in pronunciation practice. They consider that this program is very good in terms of its design on content, assessment/ flexibility, multimedia, and automatic speech recognition. It is also good in terms of its pedagogical design.

\section{CONCLUSION}

Based on the research findings and discussion, it can be concluded that the students' perception towards the use of ELSA Speak software in pronunciation class is very good. Thus, it is suggested to use this application in pronunciation practice. Furthermore, the future researcher in this field is suggested to study about the relationship between the students' perception on ELSA Speak software and their learning outcome.

\section{REFERENCES}

7 Best English pronunciation Apps. (2019). Retrieved from https://englishpost.org/bestenglish-pronunciation-apps/

Englishcentral. (2015, February 22). The 
importance of pronunciation for language learners [Web log post].

Retrieved from

https://blog.englishcentral.com/201

5/02/22/the-importance-of-

pronunciation-for-language-

learners/

Erniwati, Syafar, A., \& Marnalita. (2013).

Using audio cambridge advanced

learner's dictionary (cald) to

improve English pronunciation.

English Language Teaching

Society, 1 (1), 2331-1841.

Doi:10.22487/j23341841.2013.v1.i

1.1606

Gusrina, Amri, Z. (2013).

Englishspeak.com as media for

teaching pronunciation of junior

high school students. State

University of Padang.

Jainuri, M. (2014). Skala Pengukuran.

STKIP YPM Bangko,

Indonesia.

Martins, C. G., Levis, J. M., \& Borges, V. M. (2016). The design of an instrument to evaluate sotware for EFL/ESL pronunciation teaching. Ilha do Desterro, 69 (1), 141-160. doi: $10.5007 / 2175$ 8026.2016v69n1p141

Sasmita, E. F. (2012). The use of "Euro talk interactive" software to improve pronunciation. Tanjung Pura University.

Sholeh, A., \& Muhaji, U. (2015).

Pronunciation difficulties encountered by EFL students in Indonesia: sebuah studi kasus pada mahasiswa kelas integrated course semester 1 fkip Bahasa Inggris Universitas Kanjuruhan Malang. Jurnal Inspirasi Pendidikan, 698707. Retrieved from https://www.ejurnal.com/2016/05/pronunciationdifficulties-encountered.html 